\title{
Herpes simplex esophagitis presenting as acute necrotizing esophagitis ("black esophagus") in an immunocompetent patient
}

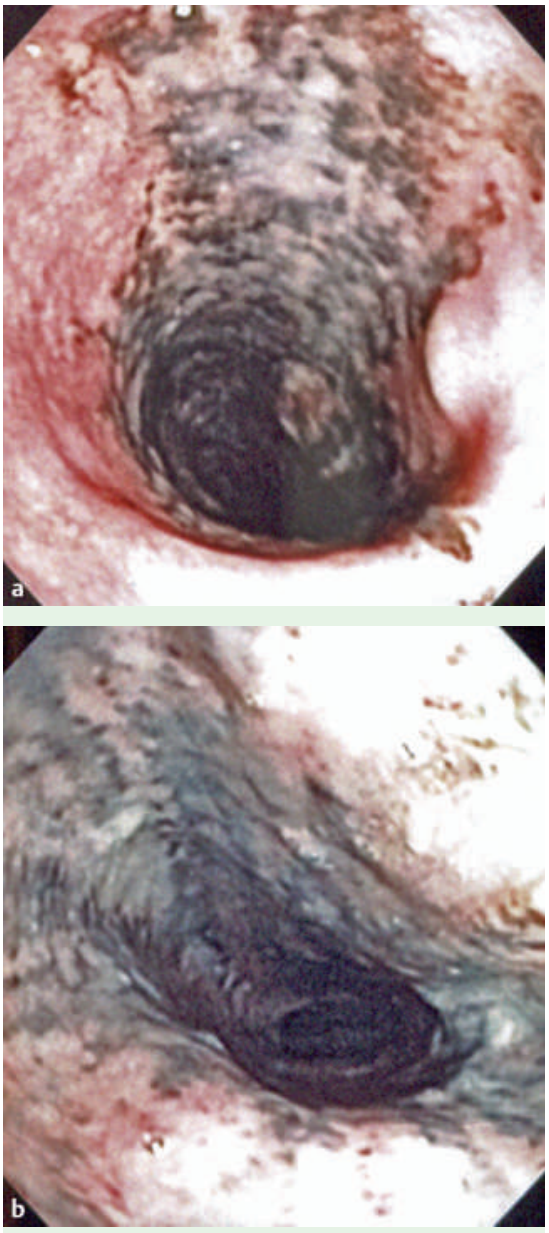

Fig. 1 a, b Endoscopic images showing "black esophagus" (necrotizing esophagitis).

"Black esophagus" is a rare condition which is defined as a dark pigmentation of the esophagus seen during endoscopy, associated with histologic mucosal necrosis. We report a case of proven herpes simplex esophagitis causing black esophagus in an immunocompetent patient. A 54-year-old man with a history of wellcontrolled schizophrenia and living in an assisted-living facility for the mentally ill was admitted to the hospital because of coffee-ground emesis and melena. The patient was hemodynamically stable on initial evaluation. His hematocrit dropped from $43 \%$ to $33 \%$ in $12 \mathrm{~h}$. Emergency upper endoscopy showed grade D esophagitis with blackish discoloration of the mucosa, mainly affecting the lower third

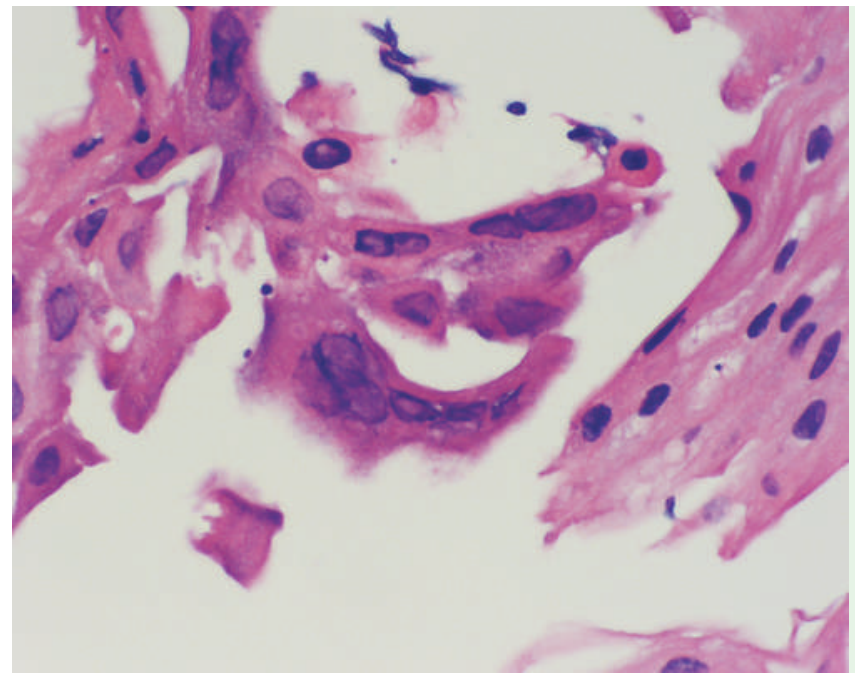

Fig. 2 High-power photomicrograph showing multinucleated giant cells with intranuclear inclusion bodies, typical of herpes esophagitis.

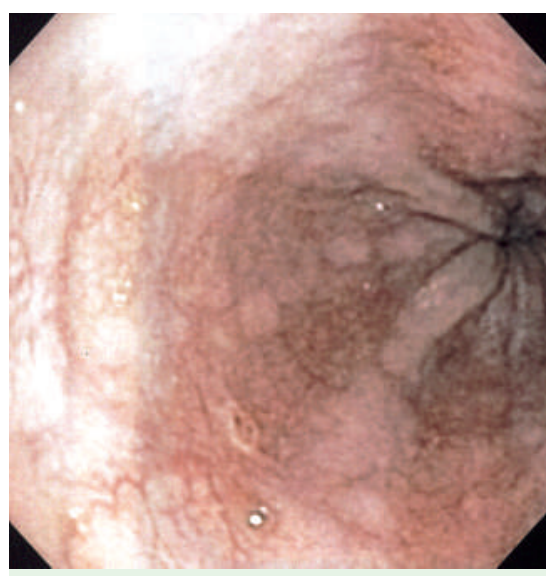

Fig. 3 Repeat esophagoscopy showed disappearance of the black lesions.

of the esophagus ( $\bullet$ Fig. 1). Esophageal biopsy showed multinucleated giant cells with Cowdry type A intranuclear inclusion bodies in epithelial cells, characteristic of herpes esophagitis ( Fig. 2). Serologic testing (IgG antibodies) for herpes simplex virus 1 was positive. The patient was treated with intravenous fluid therapy, sucralfate by mouth, and intravenous esomeprazole $40 \mathrm{mg}$ twice a day. Repeat upper endoscopy after 1 week showed healing of the mucosa except for a few tiny superficial ulcers in the esophagus (๑ Fig. 3).

Endoscopy_UCTN_Code_CCL_1AB_2AC_3AZ
S. Nagri' ${ }^{1}$, R. Hwang ${ }^{2}$, S. Anand ${ }^{1}$, J. Kurz ${ }^{3}$

1 Department of Gastroenterology, Brooklyn Hospital Center, Brooklyn, New York, USA

2 Department of Pathology, St. Barnabas Hospital, Bronx, New York, USA

Department of Gastroenterology, St. Barnabas Hospital, Bronx, New York, USA

Bibliography

DOI 10.1055/s-2007-966619

Endoscopy 2007; 39: E169

(c) Georg Thieme Verlag KG Stuttgart · New York . ISSN 0013-726X

\section{Corresponding author}

\section{S. Nagri, MD}

Department of Gastroenterology Brooklyn Hospital Center

121 Dekalb Ave

Brooklyn

NY 11201

USA

Fax: +1-347-436-4451

Krishna1973@yahoo.com 